Bangladesh J. Plant Taxon. 25(1): 51-56, 2018 (June)

(C) 2018 Bangladesh Association of Plant Taxonomists

\title{
NOTES ON THE GENUS TYLOPHORA R. BR. (ASCLEPIADACEAE) OF INDIA
}

\author{
L. RASINGAM ${ }^{1}$, J. Swamy and S. NAgaraju \\ Botanical Survey of India, Deccan Regional Centre, Plot. No. 366/1, Attapur, \\ Hyderguda Post, Hyderabad-500048, Telangana, India
}

Keywords: Tylophora; New subsp. andamanica; New combination; Andaman Islands: India.

\begin{abstract}
A new subspecies, Tylophora perakensis King \& Gamble subsp. andamanica is described and illustrated from Little Andaman Island, Andaman and Nicobar Islands, India. A new combination, Tylophora hookeriana is proposed and the distributional status of $T$. indica Merr. var. intermedia M.A. Rahman \& Wilcock is also discussed based on the fresh collections from Andaman Islands.
\end{abstract}

\section{Introduction}

The genus Tylophora R. Br. (Asclepiadaceae) consists of c. 60 species, and distributed mainly in tropical and subtropical Asia, Africa and Australia (Tseng and Chao, 2011; Murugan and Kamble, 2012). In India, Tylophora is represented by 21 species and two varieties (Jagtap and Singh, 1999; Karthikeyan et al., 2009) and recently one more species was described from the Andaman and Nicobar Islands (Murugan and Kamble, 2012). At present Tylophora R. Br. is known to be represented in Andaman and Nicobar Islands by four species viz., T. globifera Hook. f., T. indica (Burm. f.) Merr., T. flexuosa R. Br. and T. nicobarica Murugan \& M.Y. Kamble.

While working on the flora of Andaman Islands, the first author collected an interesting specimen of Tylophora R. Br. from the evergreen forests of Little Andaman Island. Critical examination of the specimens and survey of relevant literature revealed that it is morphologically similar to T. perakensis King \& Gamble but differs from shape and size of corolla which warrants sufficiently to recognize subspecies of it. Hence, it has been described as a new subspecies under T. perakensis King \& Gamble.

Tylophora perakensis King \& Gamble subsp. andamanica L. Rasingam \& J. Swamy, subsp. nov.

(Fig. 1).

Diagnosis: The new subspecies $T$. perakensis subsp. andamanica is similar to the typical subspecies, perakensis by its vegetative characters, but differs in the broadly ovate, acuminate corolla lobes with 7-9 veins (vs. oblong, obtuse corolla lobes with 3-5 veins).

Type: INDIA, Andaman and Nicobar Islands, Little Andaman Island, on the way to Ramkrishnapur dam, 19.5.2008, L. Rasingam 25991 (Holotype: CAL; Isotypes: PBL).

Paratype: INDIA, Andaman and Nicobar Islands, South Andamans, Cadell-gunj hill jungle, 25.7. 1891, Dr. King s.n. (CAL!).

A climbing shrub, up to $3 \mathrm{~m}$ long; branchlets fleshy, striate, twisted, pale brown when dry; internodes 13-15 cm long, glabrous. Leaves simple, opposite-decussate, ovate, $11-15 \times 8-9 \mathrm{~cm}$, apex acuminate; acumen up to $1 \mathrm{~cm}$ long, base deeply cordate, margin entire, membranous, glabrous; midrib slender, raised beneath, bearing a small cluster of glands at the base just above the petiole; lateral veins 9 or 10 pairs, curving upwards to anastomose near margin with an obscure looped vein; petiole upto $4.3 \mathrm{~cm}$ long, fleshy, glabrous. Inflorescence axillary or lateral

${ }^{1}$ Corresponding author. Email: rasingam@gmail.com 
between the petioles, up to $16 \times 14 \mathrm{~cm}$, as long as or longer than the leaves, divaricately branched, glabrous; peduncles 1-3 cm long, pubescent when young, later glabrescent. Flowers 5 to 11 in umbellate clusters; bracts minute, c. $0.6 \mathrm{~mm}$; pedicels $6-8 \mathrm{~mm}$ long, striate; buds ovoid, c. $3.5 \times 1.5$ mm. Calyx lobes ovate, c. $1.3 \times 1.1 \mathrm{~mm}$, apex acute, 5-7-veined, margin ciliate. Corolla campanulate-rotate; tube $0.6-0.7 \mathrm{~mm}$ long; lobes broadly ovate, acuminate, c. $3.5 \times 2.2 \mathrm{~mm}, 7$ veined, hairy inside, pubescent outside. Corona processes subglobose, c. $1 \times 2 \mathrm{~mm}$, fleshy, shorter than the anthers, point small, appressed to the anthers. Anthers slender above; appendages lanceolate, up to $1.1 \mathrm{~mm}$ long, acuminate; pollen masses globose, very minute, attached by slender, straight caudicles to the minute pollen-carriers. Style apex pentagonal, c. $1.1 \times 1.0 \mathrm{~mm}$, with convex top. Gynoecium bicarpellate, c. $1.2 \times 0.1 \mathrm{~mm}$, pubescent.

Flowering and fruiting: May to August.

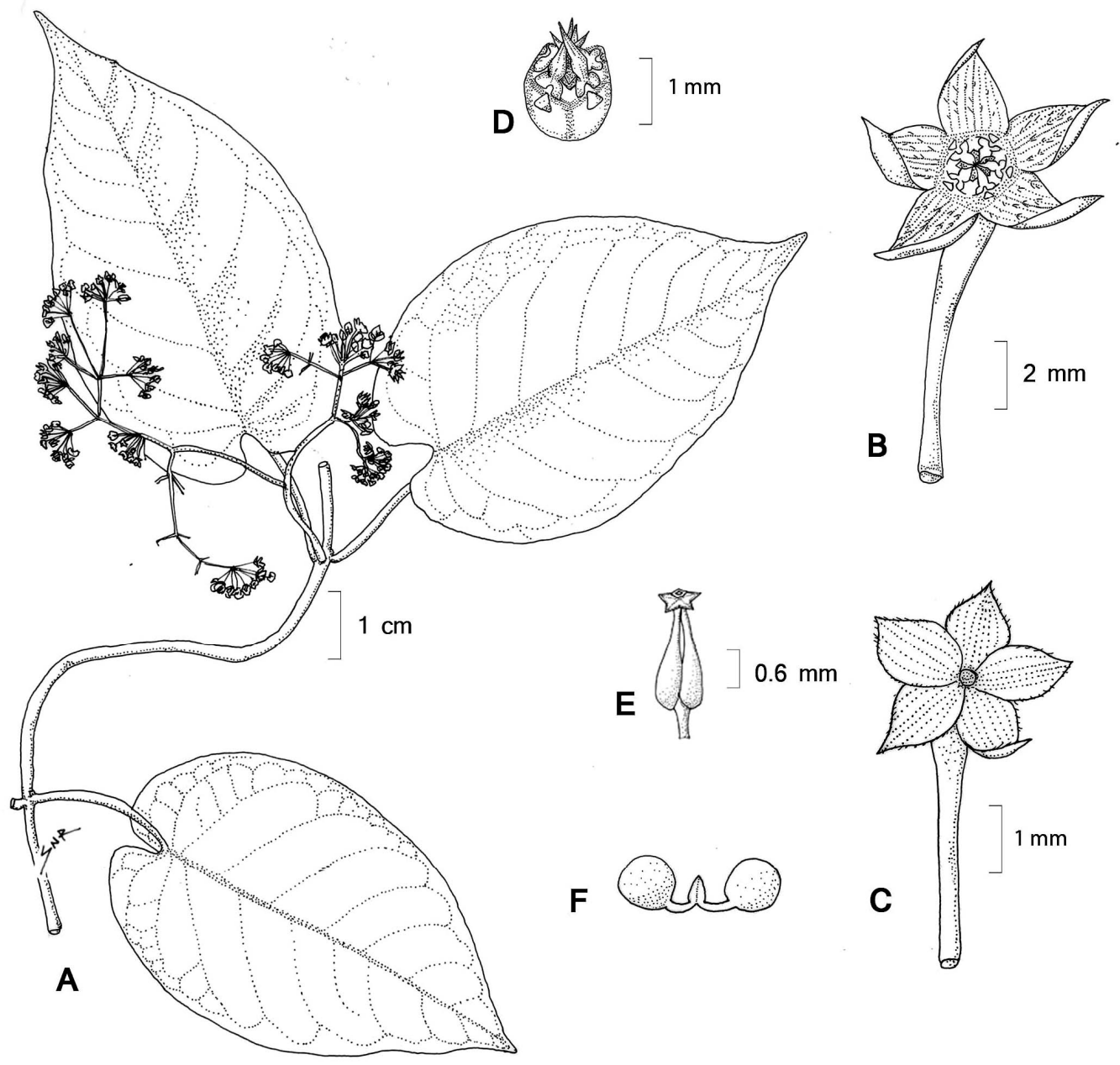

Fig. 1. Tylophora perakensis King \& Gamble subsp. andamanica L. Rasingam \& J. Swamy, subsp. nov. A. Flowering twig; B. Flower; C. Calyx; D. Corona process; E. Gynoecium; F. Pollinia. 
Habitat: Very rare on the edges of inland evergreen forests.

Distribution: India: Andaman and Nicobar Islands, Little Andaman and South Andaman Islands.

Etymology: The infraspecific epithet is named after the type locality, the Andaman Islands.

\section{Nomenclatural notes on Tylophora macrantha (Wight) Hook. f.}

T. macrantha (Wight) Hook. f. is an endemic species known from Andhra Pradesh, Kerala, Madhya Pradesh and Tamil Nadu (Karthikeyan et al., 2009). It was described by Robert Wight (1834) as a variety under T. fasciculata Buch.-Ham. ex Wight. Later, Hooker (1883) raised it to species level in his Flora of British India without knowing the name T. macrantha Hance (1882), has already been used for a species described from HongKong. Hence, T. macrantha (Wight) Hook. f. became an illegitimate later homonym, and for which, Kuntze (1891) proposed a new name, Vincetoxicum hookerianum. However, while critically studying the morphological features of the type specimen and other voucher specimens housed in CAL, MH and BSID herbaria, it is strongly felt that this species should be treated under Tylophora rather under Vincetoxicum as the diagnostic features fall well within the circumscription of Tylophora. Therefore, a new combination is proposed here.

Tylophora hookeriana (Kuntze) L. Rasingam \& J. Swamy, comb. nov. Basionym: Vincetoxicum hookerianum Kuntze, Revis. Gen. Pl. 2: 424 (1891).

Tylophora fasciculata Buch.-Ham. ex Wight var. macrantha Wight, Contr. Bot. India: 50 (1834). T. macrantha (Wight) Hook. f., Fl. Brit. India 4: 40 (1883), non T. macrantha Hance in J. Bot. 20: 79 (1882).

Type: Neelgherry, Wight Numer. List No.1540 (K, image!).

Distribution: Endemic to India: Andhra Pradesh, Kerala, Madhya Pradesh and Tamil Nadu.

Additional specimens examined: INDIA, Telangana, Amrabad Tiger Reserve, Mallayalodhi, 22.9.2013, L. Rasingam \& M. Sankara Rao 3721 (BSID); Andhra Pradesh, Srisailam Tiger Reserve, Istakameshwaram, 24.9.2014, L. Rasingam \& M. Sankara Rao 5771 (BSID); Tamil Nadu, Nilgiri district, Pykara fall, June 1884, J.S. Gamble 14239 (CAL), Coimbatore district, Dhimbam, 28.5.1905, C.E.C. Fischer 63 (CAL); North Arcot district, Vasanthapuram RF, 20.11.1977, E. Vajravelu $51989(\mathrm{MH})$.

Note: T. hookeriana resembles T. fasciculata by its habit and vegetative characters but differs by its flower length. The flowers of $T$. hookeriana are c. $7 \mathrm{~mm}$ long, whereas in $T$. fasciculata the flowers are up to $4 \mathrm{~mm}$ long.

\section{Distributional notes on Tylophora indica var. intermedia M.A. Rahman \& Wilcock}

T. indica (Burm. f.) Merr. var. intermedia M.A. Rahman \& Wilcock was described from Bangladesh and reported from India by Rahman and Wilcock (1989) based on the collections of Wight (without any locality, Wight prop. n. 1548) and Sedgwick and Bell [Bihar (Kasmar, sandy Sea shore, Sedgwick and Bell 5084, 6746)] preserved at K. While revising the family Asclepiadaceae for India, Jagtap and Singh (1999) doubted about its distribution and stated "As there is no Sea shore in Bihar state, its distribution is doubtful in India". Further, there is no report on the variety from Indian region after it was described. However, during the documentation of floral wealth of Mount Harriet National Park of Andaman and Nicobar Islands the first author had collected this variety from the Sea shores of the National Park, thus the collection confirms its distribution in India. This variety differs from var. glabra (Decne.) H. Huber by its pubescent 
stems and inflorescences and from its typical variety indica by its glabrous corolla lobes and lower surface of leaves.

Tylophora indica (Burm. f.) Merr. var. intermedia M.A. Rahman \& Wilcock in J. Econ. Taxon. Bot. 13(1): 184 (1989); Rahman \& Wilcock in Khan \& Rahman, Fl. Bangladesh 48 : 55 (1995); Jagtap \& Singh, Fasc. Fl. India 24: 161 (1999).

(Fig. 2).

A climbing shrub, up to $2 \mathrm{~m}$ long; branches minutely ridged, pale brown when dry; internodes $7-11 \mathrm{~cm}$ long, pubescent, sparsely hairy at nodes. Leaves simple, opposite-decussate, ovate or ovate-oblong, $2-5 \times 1.0-2.6 \mathrm{~cm}$, base cordate, asymmetric and hairy, margin entire, apex acuminate and mucronate, glabrous; lateral veins 4 or 5 pairs; petioles terete, $5-8 \times c .1 \mathrm{~mm}$, sparsely hairy. Inflorescence axillary umbels, as long as or slightly longer than the leaves; peduncles angled, 5$9 \times 0.4-0.5 \mathrm{~mm}$, arising between petioles nearer to one of them, hairy; bracts linear, c. $4.0 \times 0.5 \mathrm{~mm}$, apex acute, sparsely hairy; bracteole subulate, $2.0-2.5 \times \mathrm{c} .0 .3 \mathrm{~mm}$, margin sparsely hairy; pedicels filiform, 5-27 mm long, hairy. Flowers 6-7×c. $4 \mathrm{~mm}$. Calyx lobes 5, free, slightly attached at base, linear-lanceolate, $2.8-3.0 \times 0.4-0.9 \mathrm{~mm}$, hairy outside, 4 or 5-veined. Corolla rotate, c. $8.2 \times 9.2 \mathrm{~mm}$; lobes 5, united for 2.0-2.8 mm, ovate, 5.2-6.0×2.6-2.7 mm, apex obtuse, glabrous, c. 10-veined. Corona process ovate-oblong, c. $1.2 \times 2.0 \mathrm{~mm}$, uniseriate, 5-lobed, adnate below the staminal column with free points above. Stamens 5 , c. $1.0 \times 0.6 \mathrm{~mm}$; pollinia 5 , pollen masses

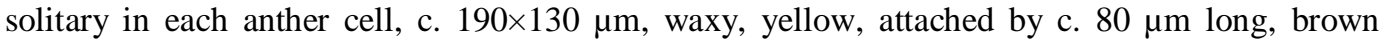
caudicles; corpusculum c. $110 \times 70 \mu \mathrm{m}$, dark brown. Gynostegium c. $2.2 \mathrm{~mm}$ long; carpels 2, c. $1.6 \times 1.0 \mathrm{~mm}$, glabrous; style apex pentagonal, c. $1.1 \times 0.4 \mathrm{~mm}$.

Flowering and fruiting: March to September.

Habitat: Very rare along the littoral forests.

Distribution: India (Andaman Islands), Bangladesh, Myanmar and Sri Lanka.

Specimen examined: INDIA, Andaman and Nicobar Islands, Mount Harriet National Park, near north Bay, 10.3. 2007, L. Rasingam 2982 (BSID).

\section{Key to the Tylophora species in Andaman and Nicobar Islands}

1. Leaves deeply cordate at base T. perakensis subsp. andamanica

- Leaves truncate, rounded to cordate at base

2. Flowers small, in much branched panicles or corymbose cymes

- Flowers large, in simple or rarely branched umbellate cymes and racemes

3. Flowers in simple or branched umbellate racemes

- Flowers in simple umbellate cymes

T. tetrapetala

3

T. nicobarica

. Plants quite glabrous; sepals ovate-lanceolate; coronal scales globose, very large

- Plants pubescent; sepals linear or linear-lanceolate; coronal scales ovoid, small

T. globifera

5. Lower surface of the leaves and corolla lobes glabrous

- Lower surface of the leaves and corolla lobes pubescent

T. indica var. intermedia

T. indica var. indica 


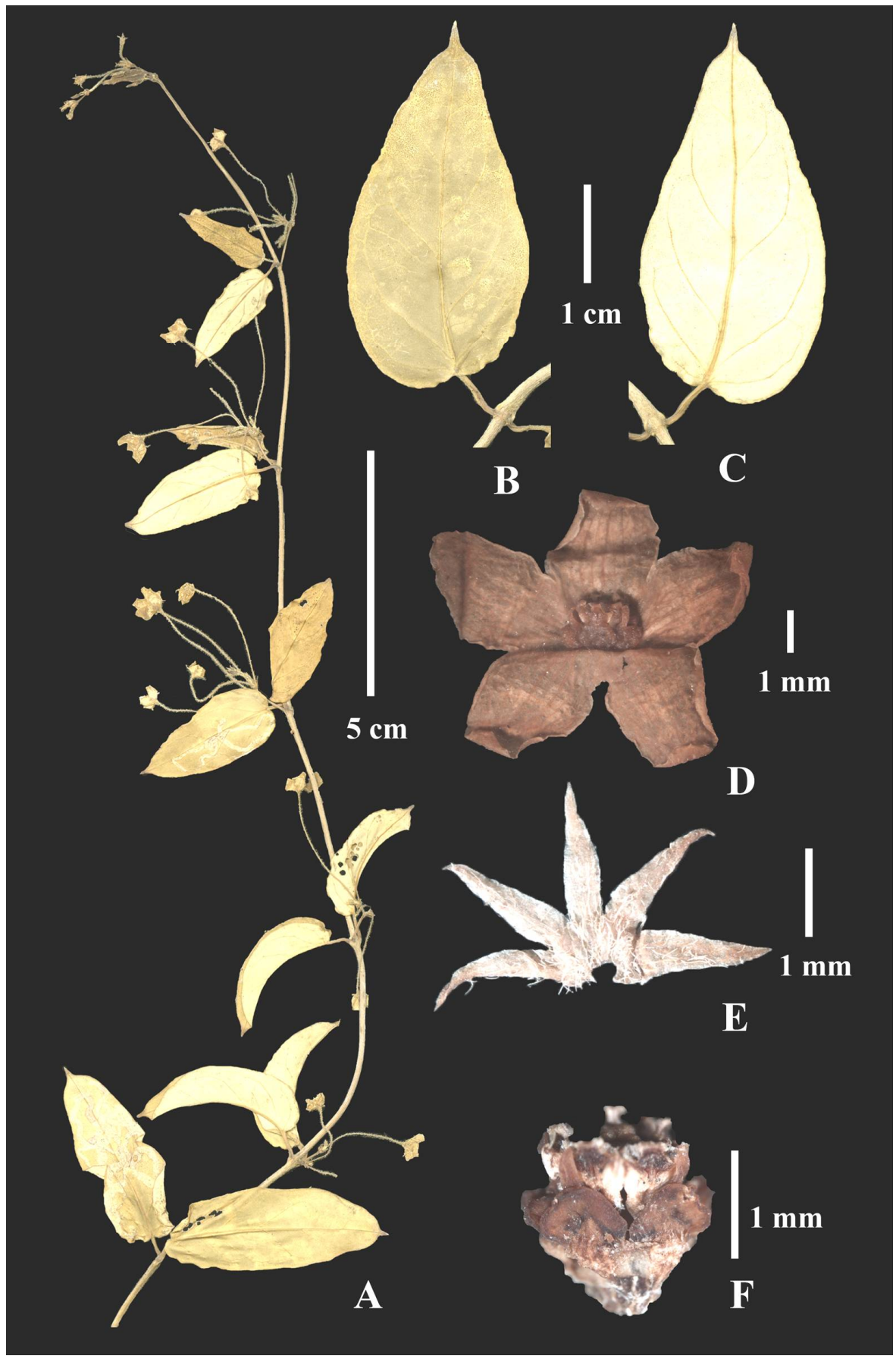

Fig. 2. Tylophora indica (Burm. f.) Merr. var. intermedia M.A. Rahman \& Wilcock A. Flowering twig; B. Leaf - adaxial view; C. Leaf - abaxial view; D. Open flower; E. Calyx; F. Gynostegium. 


\section{Acknowledgements}

The authors are grateful to Dr. P. Singh, Director, Botanical Survey of India, Kolkata and Dr. M. Ahmedullah, Scientist-E, Botanical Survey of India, Deccan Regional Centre, Hyderabad for facilities and encouragements. We are also thankful to the officials and field assistants of Andaman and Nicobar Forest Plantation \& Development Corporation Ltd., and Hut Bay for field support.

\section{References}

Hance, H.F. 1882. A decade of new Hong-Kong Plants. J. Bot. 20: 77-80.

Hooker, J.D. 1883. Asclepiadaceae. In: Hooker J.D. (Ed.), The Flora of British India. Vol. 4. L. Reeve \& Co., London, pp. 1-78.

Jagtap, A. and Singh, N.P. 1999. Asclepiadaceae and Periplocaceae. Fascicle of Flora of India. Fascicle 24: 1-332. Botanical Survey of India, Calcutta.

Karthikeyan, S., Sanjappa, M. and Moorthy, S. 2009. Flowering Plants of India. Dicotyledons. Volume 1 (Acanthaceae-Avicenniaceae). Botanical Survey of India, Kolkata.

Kuntze, O. 1891. Revisio Generum Plantarum: vascular iumomnium at quecellular iummultarum secund umleges nomeclaturae internationales cum enumerationeplantarumexoticarum in itinere mundi collectarum, Pars II. Dulau \& Co, 37, Soho Square, London, p. 424.

Murugan, C. and Kamble, M.Y. 2012. A new species of Tylophora (Apocynaceae-Asclepiadoideae Asclepiadeae) from the Nicobar Islands, India. Rheedea 22(2): 83-87.

Rahman, M.A. and Wilcock, C.C. 1989. Notes on tropical Asian Asclepiadaceae - II. J. Econ. Taxon. Bot. 13(1): 181-185.

Tseng, Y.H. and Chao, C.T. 2011. Tylophora lui (Apocynaceae), a new species from Taiwan. Ann. Bot. Fennici 48: 515-518.

Wight, R. 1834. Asclepiadeae Indicae. Contributions to the Botany of India, Parbury, Allen \& Co., London, pp. 29-67. 